\title{
Narrativas digitais sobre os exames de admissão ao ginásio: ego- documentos e cultura escrita na história do tempo presente ${ }^{1}$
}

\begin{abstract}
Resumo
A proposta deste artigo é discutir narrativas digitais escritas em primeira pessoa, tomadas em seu sentido mais amplo de egodocumentos. Foram analisados 12 blogs e 4 sites pessoais que trazem histórias escritas sobre os exames de admissão ao ginásio (que vigoraram no Brasil entre 1931 e 1971), bem como os comentários relativos a cada postagem. A análise das narrativas foi desenvolvida a partir de três eixos irredutivelmente articulados: o primeiro deles é metodológico e requer problematizar as possibilidades e limites de se explorar blogs e sites como fontes históricas adequadas para se compreender os fenômenos contemporâneos da memória, da narrativa e das temporalidades. O segundo eixo implica analisar as narrativas postadas nos blogs e sites como fenômenos que contribuem para dotar de inteligibilidade a história da cultura escrita no tempo presente. $O$ terceiro eixo de análise impõe uma reflexão sobre os sentidos do passado e da memória nas escritas de si. As questões aqui levantadas lidam com os desafios sobre a significação e interpretação do tempo pelos sujeitos do presente. Se se considera que narrar a própria vida é uma necessidade transcultural relativa à significação da existência, é irrenunciável pensar nas mudanças operadas na experiência humana e sua relação com a historicidade depois que a hiperconectividade, possibilitada pela web 2.0, alterou significativamente os fluxos do tempo e do espaço.
\end{abstract}

Palavras-chave: Cultura escrita; Narrativas digitais; Exames de admissão ao ginásio.

\section{Para citar este artigo:}

SILVA, Cristiani Bereta da. Narrativas digitais sobre os exames de admissão ao ginásio: egodocumentos e cultura escrita na história do tempo presente. Revista Tempo e Argumento, Florianópolis, v. 7, n.15, p. 05 - 41. maio/ago. 2015.

\section{DOI: $10.5965 / 2175180307152015005$}

http://dx.doi.org/10.5965/2175180307152015005

\footnotetext{
${ }^{1}$ As discussões aqui apresentadas trazem resultados de duas ordens de trabalhos distintas, mas convergentes. $O$ primeiro refere-se ao projeto de pesquisa Exames de admissão ao ginásio: livros, narrativas e memórias na construção da disciplina escolar de História (Décadas de 1930-1970), aprovado pelo CNPq (Processo: 304878/2012-0) com concessão de bolsa produtividade para o triênio 2013-2016, na área de História. O segundo trata dos estudos relativos às escritas de si e história da cultura escrita realizados junto ao Departamento de Historia e Filosofia, da Universidade de Alcalá, Madrid, sob a supervisão do Prof. Dr. Antonio Castillo Gómez, no período de fevereiro a julho de 2015, com a concessão de bolsa CAPES-Estágio sênior no exterior (Processo: BEX/5955/14-9).
} 


\title{
Digital narratives of brazilian middle school entrance exams: ego-documents and culture written in present time history
}

\begin{abstract}
The proposal of this article is to discuss digital narratives written in first person, in the broadest sense of ego-documents. Twelve blogs and 4 personal websites were analyzed as to stories written about brazilian middle school entrance exams (in effect between 1931 and 1971), as well as comments made on each post. The analysis of narratives was developed from 3 articulated axes: firstly, a methodological problematization of the possibility and limits in exploring blogs and sites as historical sources adequate to understand contemporary phenomena of memory, narratives, and temporalities. The second axis implies the analysis of narratives posted on blogs and sites as phenomena that contribute into adding intelligibility to the history of written culture in present times. The third axis of analysis imposes a reflection on the sense of past and of memory in the writing itself. Issues raised here deal with challenges on the interpretation and signification of time by present-time subjects. If considering that narrating one's own life is a transcultural need related to giving meaning to one's own existence, to consider changes in human experience and its relation to historicity is unremitting, particularly after the hyperconnectivity enabled by Web 2.0 has significantly altered the flow of space and time.
\end{abstract}

Keywords: Written culture; Digital narratives; Entrance exams. 
Las historias se narran, la vida se vive.

(RICOEUR, 2006, p. 15)

Inicio o texto por meio desse paradoxo porque entendo que sua compreensão permite melhor cercar o objeto da discussão aqui proposta: a necessidade quase que irrenunciável de narrar a vida que os seres humanos possuem e de como essa necessidade possibilita compreender determinados fenômenos históricos associados aos usos e funções da escrita em suportes digitais, no presente.

Segundo Paul Ricoeur $(2006,2010)$ o que poderia ser um abismo entre o relato e a vida ou entre a ficção e a vida na verdade não é. Primeiro porque é necessário ter em mente que vida e vivido aludem a significados diferentes. Vida é um fenômeno biológico enquanto que vivido é um fenômeno cultural relativo à experiência de viver, espaço temporal entre o nascimento e a morte em que os seres humanos vivenciam processos de "agir e sofrer". A trama de uma vida constituir-se-ia nessa intersecção entre formas que se alternam ou se sobrepõem de agir e de sofrer. E aí, nessa clave, relato e vida podem ser reconciliados, "ya que la propia lectura es ella misma una manera de vivir en el universo ficticio de la obra; en este sentido, ya podemos decir que las historias se narran, y también se viven imaginariamente." (RICOEUR, 2006, p. 16-17, grifos no original). Isso porque o processo de configuração não termina no texto, mas sim no leitor, possibilitando a reconfiguração da vida por meio do relato, "Más concretamente: el sentido o el significado de un relato surge en la intersección del mundo del texto con el mundo del lector" (RICOEUR, 2006, p. 15, grifos no original).

Entre as inúmeras formas de narrar a vida, a escrita tem guardado uma especial relação com a dimensão espacial e temporal da existência e atividades humanas, desde sua aparição, há pelo menos 5000 anos. Viñao Frago (2002, p. 353) destaca que foi a escrita que permitiu salvar o caráter efêmero da oralidade, possibilitando a recuperação do escrito em outros espaços e tempos diferentes daqueles em que foi produzido originalmente. Durante muito tempo, escreveu-se apenas à mão e os manuscritos eram 
resultados de uma prática coletiva. Mesmo com a imprensa após o século XV, a escrita como prática coletiva permaneceria. Na Europa, só a partir do século XIX ela viria a se tornar individualizada ou mesmo autobiografizada (LEJEUNE, 2008, p. 324). O fato é que a escrita como prática coletiva ou individual, manuscrita ou impressa, promoveu uma nova consciência da temporalidade, a partir do fluxo do tempo ligado à textualidade. Relação que a imprensa certamente reforçou, muito embora não tenha produzido imediatamente novas formas de leitura, já que "as mudanças na ordem das práticas costumam ser mais lentas que as revoluções das técnicas" (CHARTIER, 2009, p. 63). Mas a consciência da temporalidade e da textualidade, assim como a estreita relação entre elas na longa duração, favoreceria o desenvolvimento da consciência histórica ao confrontar o passado e o presente (VIÑAO FRAGO, 2002, p. 354). Tal confrontação ressignificaria a própria ideia da finitude reposicionando o lugar da escrita na história dos seres humanos.

Chartier (2006) analisa que o medo da perda assombrou as sociedades europeias nos séculos XVI e XVII. A fim de conjurar esse perigo, elas se dedicaram a fixar na forma escrita os vestígios do passado, a memória dos mortos ou a glória dos vivos, e todas as histórias que não deveriam desaparecer. Porém, ainda segundo este historiador, o excesso dos escritos, que multiplica os textos inúteis e sufoca o pensamento sob os discursos acumulados, "fue percebido como un riesgo tan grande como su contrario. Temido, el borrar era entonces necessário, como lo es olvido para la memoria" (CHARTIER, 2006, p. 10). A compreensão da tensão entre a inquietude da perda e o temor do excesso, da relação entre o sentido da experiência humana e o tempo, mediados pelas narrativas, passa pela história da cultura escrita. História aqui compreendida a partir dos estudos de Castillo Goméz (2002; 2003; 2012) como uma proposta que visa superar a distinção tradicional entre a história da escrita, por um lado, e a história do livro e da leitura, por outro, para fazê-las convergir a um espaço comum: o da história social da cultura escrita, cuja tarefa seria: “el estudio de la producción, difusión, uso y conservación de los objetos escritos, cualquiera que sea su concreta materialidad - del documento oficial a la carta privada - o soporte - de la tablilla de arcilla a la pantalla electrónica" (CASTILLO GÒMEZ, 2002, p. 19). 
Contudo, essas relações - entre guardar a memória dos vivos em suportes escritos e mesmo a própria cultura do escrito - sofreram deslocamentos importantes (ainda em curso) com a revolução empreendida pelas tecnologias da informação e da comunicação (TICs) a partir da segunda metade do século XX. Claro está que não se trata apenas de alterações quanto às técnicas, mas sim de suas ressonâncias nas experiências de leitura e de escrita. Isso porque essa revolução - já no século XXI configurada como Web $2.0^{2}$ possibilitou a existência de uma esfera digital como espaço de virtualidade hiperconectado que provocou mutações significativas nas formas de narrar a vida e nas relações estabelecidas entre a escrita e a oralidade. Certamente essas mutações possuem também implicações nas subjetividades, nas relações estabelecidas entre os sujeitos e as temporalidades, os sentidos de passado e de experiência e as expectativas de futuro. No presente, narrativas em suportes digitais convertem-se em documentos importantes para se analisar novos formatos de escritas de si, subjetividades e a história da cultura escrita. Nessa direção, este artigo analisa formas de narrar a vida por meio de postagens sobre os exames de admissão ao ginásio ${ }^{3}$ em diferentes blogs ${ }^{4}$ e sites ${ }^{5}$ pessoais. A ideia é perceber como esses textos escritos em primeira pessoa fazem usos do passado e evidenciam interpretações sobre o tempo ao inscreverem memórias sobre a experiência da escolarização.

\footnotetext{
${ }^{2}$ A expressão objetiva marcar uma nova etapa de desenvolvimento da internet. Grosso modo se refere aos formatos da web que se caracterizam por facilitar a intercomunicação entre leitores, compartilhamento de informações e interatividade. Ver: SIBILIA, 2008, p. 14; ESCANDELL MONTIEL, 2014, p. 46.

${ }^{3} \mathrm{O}$ exame de admissão ao ginásio foi instituído com a Reforma Francisco Campos, pelo Decreto n. 19.890 de 18 de abril de 1931, que reformou o Ensino Secundário e perdurou oficialmente até 1971, quando foi extinto pela Lei 5.692/71, que fixou diretrizes e bases para o ensino de $1^{\circ}$ e $2^{\circ}$ graus. Durante quarenta anos, estudantes do primário que desejavam ascender ao ginásio submeteram-se a provas orais e escritas, que possuíam caráter eminentemente excludente.

${ }^{4}$ Segundo Escandell Montiel (2014, p. 17-18; 20) é difícil precisar a data da emergência do formato weblog, pois foram muitas as iniciativas parecidas que surgiram em diferentes lugares, a partir da segunda metade da década de 1990. Mas a expressão blog surge em 1999, quando Peter Merholz coloca a palavra, com certa intenção humorística, na lateral direita de seu weblog Peterme.com, fazendo um jogo com as palavras "we blog", que seria, por sua vez, a contração da sentença completa: "we blog because we weren't very popular in high school and we're trying to gain respect and admiration without actually having to be around people".

${ }^{5}$ Um blog também é um site, mas um site não é um blog. Pode-se dizer que a criação de um site exige requisitos de programação mais complexos que a de um blog. Além disso, os sites costumam ser criados para informar produtos/serviços de uma determinada empresa. Esclarece-se, porém, que os sites citados nesse artigo não se referem a empresas, mas sim a pessoas físicas que criaram um site como meio para publicizar seu trabalho e também falar de si. Entre administradores desses sites há, por exemplo, escritores/poetas e também um pastor (Igreja Evangélica Congregacional).
} 
Meu encontro com as narrativas digitais se deu quando utilizava ferramentas de buscas na Internet com objetivo de mapear estudos e informações sobre os exames de admissão ao ginásio. Tais buscas me direcionaram para mais de uma dezena de blogs e sites pessoais que traziam depoimentos nostálgicos e românticos sobre "o tempo dos exames". Descobri homens e mulheres assumindo o papel de narradores de versões de uma história que era também meu objeto de pesquisa. Mas eram outras histórias e descobri nelas um gosto - e uma possibilidade de trabalho - que ainda não tinha provado e descoberto com os outros documentos mapeados até então. Eram narrativas postadas em blogs ou sites, administrados pelo próprio narrador ou postados por outros leitores/autores que participavam dessa rememoração com suas histórias ou comentários, sobre as experiências consideradas inesquecíveis dos tempos de escola.

Essas considerações e a leitura de algumas das histórias postadas nesses espaços virtuais redimensionaram a pesquisa em andamento sobre os exames, pois percebi a necessidade de também pensar as narrativas e os próprios sites em sua singularidade como fontes para a pesquisa histórica no tempo presente. São narrativas de si, memórias individuais e coletivas inscritas numa espécie de "janela sempre aberta e ligada a dezenas de pessoas ao mesmo tempo" (SIBILIA, 2008, p. 12) e que carecem de mobilização de ferramentas de análise diferentes daquelas selecionadas para se pensar os livros didáticos e demais documentos da pesquisa já citada, como os relatórios das escolas sobre os exames, por exemplo.

Foram encontrados e catalogados 12 blogs, 4 sites e respectivos comentários, que trazem narrativas dedicadas aos exames de admissão ao ginásio. Para a escrita desse artigo foram selecionados os textos e imagens considerados mais capazes de representar esse universo. Essas narrativas são analisadas a partir de três eixos diferentes, irredutivelmente articulados e aqui separados apenas para tentar dar melhor clareza à discussão: o primeiro deles é metodológico e requer problematizar as possibilidades e limites de se explorar blogs e sites como fontes históricas adequadas para se compreender os fenômenos contemporâneos da memória, da narrativa e das temporalidades. O segundo eixo implica analisar as narrativas postadas como fenômenos que contribuem para dotar de inteligibilidade a história da cultura escrita no tempo 
presente. Campo fértil de investigação, e particularmente assolado pelas inquietações advindas das significativas transformações ocorridas nas técnicas da produção da escrita, seus suportes e modalidades de sua apropriação, como bem pontua Castillo Gómez (2002, p. 150): “Nos hallamos en el camino sin retorno a las redes digitales y estas necessariamente implican otros modos de relacionarse com la materia escrita e incluso puede que nuevos e importantes desarrollos para la cultura del texto".

O terceiro eixo de análise impõe uma reflexão sobre os sentidos do passado e da memória nas escritas de si. Nesse estudo, as narrativas digitais são entendidas como escritas de si, tomadas em seu sentido mais amplo de ego-documento. O termo egodocumento foi cunhado pelo historiador holandês Jacob Presser, em 1958, para designar "la diversidad de las formas de expresión escrita de los sentimientos y experiencias personales. Desde su punto de vista, un ego-documento es un texto, de cualquier forma o tamaño, 'en el que se esconde o descubre deliberada o accidentalmente un ego"' (AMELANG, 2005, p. 17). Tal conceito ganhou reconhecimento no mundo acadêmico, repercutindo também na produção historiográfica que deslocou sua atenção para a amplidão de testemunhos escritos - cartas, diários, crônicas de família, diários de viagem, entre outros. No presente, redes sociais, blogs e sites pessoais diversificaram os suportes desses escritos, alargando ainda mais os gêneros textuais que possuem reinvindicações do eu.

Mesmo em suportes diferentes, as narrativas digitais aqui tratadas têm em comum a forma escrita em primeira pessoa, cujo reflexo narrativo são as experiências pessoais do narrador/escritor. Essa reflexão coloca desafios sobre a significação e interpretação do tempo pelos sujeitos do presente. Pois, se se parte da ideia de que "existe, entre a atividade de narrar uma história e o caráter temporal da experiência humana, uma correlação que não é puramente acidental, mas que apresenta uma forma de necessidade transcultural" (RICOEUR, 2010, p. 92) e de que a internet alterou significativamente os fluxos do tempo e do espaço, é irrenunciável que pensemos sobre as mudanças operadas na experiência humana em sua relação com a historicidade. 


\section{Blogs e sites pessoais como fontes históricas para a escrita da história do tempo presente}

Toda fonte é uma fonte "inventada".

(ROUSSO, 1996, p. 87)

“A história oral está para a escrita da história do tempo presente como a arqueologia está para a escrita da história antiga”. Esse foi um dos argumentos sobre o qual construí parte das reflexões sobre a história do tempo presente, a fim de fundamentar algumas questões da minha tese de doutorado, há mais de uma década, e que foram publicadas como um artigo tempos depois (SILVA, 2006). Hoje não poderia mais dizer apenas história oral e sim também acrescentar a Internet. Claro está que nem todo o trabalho com a história oral ou com a Internet inscreve-se como uma história do tempo presente. Contudo, se pode afirmar que, nos últimos anos, a pesquisa histórica realizada no e sobre o presente não pôde mais prescindir da Internet como lugar de possibilidade de uma nova categoria de fontes documentais.

Entendo que a história do tempo presente emerge como um novo domínio na operação historiográfica e não como um marco temporal cronológico acrescentado à clássica organização quadripartite da história. Pode-se dizer que lida com escalas temporais que tanto podem estar localizadas num passado mais distante quanto num mais recente, mas que de igual maneira remetem a problemas do passado que interpelam fortemente o presente. Lida, assim, com questões relacionadas a um passado que não passa, particularmente aquelas relativas aos fenômenos da memória (disputas, interditos de determinados esquecimentos, comemoração, patrimônio, arquivística etc.) e deslocamentos em relação à percepção das temporalidades (o Telos dando lugar ao Kairos).

Na análise de François Dosse (2012, p. 6), essa nova concepção da operação historiográfica estaria "na intersecção do presente e da longa duração". Ainda segundo este historiador, a percepção das sucessivas crises - após a segunda metade do século XX - resultou num pessimismo em relação à história ou mesmo numa descrença na ideia de 
progresso contínuo, possibilitando a emergência de uma relação temporal totalmente nova; o presente tanto seria alargado quanto iria fechar-se em si mesmo, produzindo um "presenteísmo dominante" (DOSSE, 2001). Fenômeno que sugere a efervescência das comemorações, do interdito do esquecimento, da importância da memória que colocaram em pauta o instante, o presente em contraposição ao "império do passado". Contudo, as mesmas décadas que evidenciaram a dissolução do passado e a sua celebração também trouxeram com força a expansão memorialística, com suas museificações e institucionalização de passados-espetáculo, "das aldeias Potemkin ${ }^{6}$ e dos theme-parks históricos" (SARLO, 2007, p. 11). Esse movimento teve como efeito também outras e novas formas de experimento da historicidade, pois implicou na redefinição da noção de acontecimento "como abordagem a uma multiplicidade de possíveis, de situações virtuais, potenciais, e não mais como algo consumado em sua fixidez" (DOSSE, 2001, p. 92).

Ao deixar de ser apenas um espaço de tempo compreendido como um lapso ahistórico, o presente denotou um campo cheio de possibilidades aos historiadores dispostos a vencer seus desafios. Esse alargamento dimensionaria a complexidade da relação mantida entre o historiador e um tempo que lhe reserva "contatos demasiados ardentes" (BLOCH, 2001, p. 61) e também colocaria em pauta o presente como tempo historicamente construído. Sobre isso, Luisa Passerini (1996), inspirada em Hannah Arendt, salienta a importância de não esquecer que o presente sobre o qual nos debruçamos não é um lugar de passagem entre um antes e um depois, uma lacuna entre o passado e o futuro, mas sim, um campo de forças constituído a partir do pensamento humano. Uma noção que permite entender melhor aquilo que o presente pode comportar de descontinuidade, de ruptura, de ponte entre o passado e o futuro. Construção histórica, o tempo não é um continuum, pois se interrompe no ponto onde o

\footnotetext{
${ }^{6}$ Diz-se que o príncipe e ministro russo Grigory Aleksandrovich Potemkin construiu aldeias de fachada para impressionar a czarina, Catarina II, durante sua visita à Crimeia, em 1787. As aldeias de fachada teriam sido erigidas ao longo das margens do rio Dniepre (Catarina II viajava de barco) para darem a impressão de uma pujança colonizadora que não existia. Essa versão não foi comprovada, muitos historiadores duvidam dela ou consideram-na um exagero. No entanto, "aldeia Potemkin" passou a significar, especialmente em um contexto político, uma farsa literal ou figurada para fins de propaganda. Disponível em: http://en.wikipedia.org/wiki/Potemkin_village. Acesso em: 16 mai. 2015.
} 
ser humano se encontra. Partindo desse pressuposto, compreende-se que a história, em especial a história do tempo presente, contribui "para criar a lacuna que cada geração nova, cada ser humano deve descobrir e preservar mediante um trabalho assíduo" (PASSERINI, 1996, p. 114).

Importante não esquecer também que tanto a leitura do passado recente quanto a do passado distante se organizam em função de interpretações e problemas sempre situados no presente. Michel de Certeau (1982) há muito já chamou a atenção de que a operação historiográfica se organiza a partir de regras próprias, constituindo parte da realidade de que trata, numa relação entre um lugar social, uma prática e uma escritura. $O$ trabalho do historiador é, portanto, tributário de seu tempo; de suas escolhas e intervenções mediadas por critérios validados pelas pertinências da prática disciplinar e organizados a partir da particularidade de seu lugar social.

Ainda na década de 1940, o historiador Marc Bloch (2001, p. 79) já afirmava que "a diversidade dos testemunhos históricos é quase infinita. Tudo o que o homem diz ou escreve, tudo o que fabrica, tudo o que toca pode e deve informar-nos sobre ele". Este artigo trabalha com essa definição bastante alargada e atual de "fonte histórica", bem como a ideia de que a história não se restringe ao passado puramente, mas sim aos homens e mulheres no tempo. Nessa direção, considero que textos escritos em primeira pessoa veiculados em blogs e sites pessoais convertem-se em fontes documentais imprescindíveis para se pensar as relações estabelecidas entre passado, presente e futuro, posto que evidenciam as dimensões subjetivas das vinculações entre determinados sujeitos com acontecimentos passados e de como esses acontecimentos são selecionados, reelaborados e produzidos como memórias.

Claro está que não somente aqueles que se dedicam a estudos relativos a um passado recente ou a história do tempo presente, têm na Internet uma fonte inesgotável de recursos. Diferentes fundações, bibliotecas, projetos de investigação específicos etc. mantêm arquivos de diferentes documentos digitalizados na internet que não se circunscrevem a passados recentes. ${ }^{7}$ Mas textos escritos em suportes específicos como

\footnotetext{
${ }^{7}$ Apenas para ilustrar, cito aqui alguns endereços que disponibilizam documentos digitalizados. Jornais e/ou revistas, por hemerotecas digitais, por exemplo, Biblioteca Nacional de España:
} 
em blogs e sites pessoais, não pertencem a mesma ordem desses documentos virtuais, não estão reunidos num arquivo específico, constituído objetivamente para fins de pesquisa.

O trabalho com fontes históricas inventariadas na Internet também desloca a própria noção de arquivo na operação historiográfica. Desde a emergência do método crítico e do historiador profissional, no século XIX, a questão do "arquivo" ocupou um lugar central nos debates historiográficos. Mas esse lugar foi desestabilizado e modificado com o uso de entrevistas orais e o surgimento de uma história do tempo presente, que implicaria "na confrontação direta e o diálogo permanente com os vestígios vivos do passado - a memória dos atores" (ROUSSO, 1996, p. 85). A partir de então, o arquivo não é mais percebido como o repositório de "documentos verdadeiros" sobre o passado, lugar quase que sacralizado no qual os historiadores devem aceder para buscar "a prova", a fonte de comprovação de determinado fato histórico. O arquivo, no presente, é um lugar físico ou virtual onde documentos originais ou reconstituídos são conservados, organizados em diferentes acervos. Desde este ponto de vista, o arquivo perde sua acepção clássica de lugar “de prova”, constituindo-se assim e um lugar de pesquisa dentre outros, que fazem parte da prática historiográfica.

Se se concorda com essa noção alargada de arquivo bem como a de documento, pode-se acompanhar o argumento de Henry Rousso (1996), de que existem mais características comuns a toda fonte histórica que diferenças inconciliáveis. Nesse sentido, o que faz com que um documento seja pertinente (ou não) para determinada pesquisa, não é seu formato (texto, oral, audiovisual, icônico, fotográfico etc.), nem seu suporte

http://www.bne.es/es/Catalogos/HemerotecaDigital/. Acesso em 22 mai. 2015. Biblioteca Nacional (Brasil) http://bndigital.bn.br/hemeroteca-digital/. Acesso em 22 de mai. 2015. Biblioteca Pública do Estado de Santa Catarina: http://hemeroteca.biblioteca.sc.gov.br/HEMO.html. Acesso em 22 de mai. 2015. Acervo digital da revista Veja que disponibiliza todos os números publicados, desde sua fundação, em 1968. http://veja.abril.com.br/acervodigital/home.aspx. Acesso em 22 de mai. 2015. Documentos diversos: Ofícios, relatórios etc. emitidos pelo poder executivo do Brasil entre 1821 e 1993, disponibilizados pelo Center for Research Libraries (CRL), com sede em Chicago: http://wwwapps.crl.edu/brazil. Acesso em 22 de mai. 2015. Documentos que vão desde cartas pessoais a relatórios de governo de países da Europa, América e Ásia, referentes ao projeto criado e desenvolvido pelo professor Arnau González i Vilalta, da Universitat Autònoma de Barcelona, com o apoio de instituições catalãs e entidades privadas: http://documentsforhistory.com/pt/portada/. Acesso em 22 de mai. 2015. 
(papel, argila, digital etc.), nem se é original ou reconstituído, mas sim fundamentalmente as boas e velhas perguntas feitas previamente pelo historiador.

Certamente este procedimento não está isento de neutralidade, posto que "não existe um documento objetivo, inócuo, primário" (LE GOFF, 2003, p. 545), afinal toda a prática historiográfica é marcada indelevelmente pelo lugar social de sua produção, e é em "função deste lugar que se instauram os métodos, que se delineia uma topografia de interesses, que os documentos e as questões, que lhes serão propostas, se organizam" (CERTEAU, 1982, p. 66). Com base nessas premissas, entendo que os blogs e sites pessoais selecionados para esta pesquisa podem também ser compreendidos sob a noção de documento/monumento da qual trata Le Goff (2003). Primeiro porque são testemunhos do passado - mesmo que escritos no presente -, efeitos de escolhas de indivíduos que consciente ou inconscientemente julgam ser importantes para serem legados a uma nova geração que não viveu "no tempo dos exames de admissão". Segundo, porque podem constituir-se em uma série documental, um acervo (particular, do próprio investigador e/ou do grupo de pesquisa a qual pertence), a depender da intervenção do historiador, que decide sobre aquilo que ele irá considerar como testemunho do passado e o que ele irá rejeitar. Mais do que nunca, neste caso também é a prática histórica que "transforma os documentos em monumentos" (LE GOFF, 2003, p. 103).

Se se concorda que há mais semelhanças do que diferenças entre as fontes históricas, há que se considerar que as disponíveis na Internet possuem um caráter de efemeridade que exigirá cuidados específicos por parte do historiador. Por exemplo, muitos blogs e sites são retirados do ar sem aviso prévio, inviabilizando a consulta. Uma possibilidade para seguir consultando o material é armazená-lo, salvando-o em arquivos em formato Portable Document Format (PDF) ${ }^{8}$, o que permite a construção de um banco

\footnotetext{
8 Formato de arquivo usado para exibir e compartilhar documentos de maneira compatível, independentemente de software, hardware ou sistema operacional. Inventado pela Adobe, o PDF agora é um padrão aberto mantido pela International Organization for Standardization (ISO). PDFs podem conter links e botões, campos de formulário, áudio, vídeo e lógica de negócios. Eles também podem ser assinados eletronicamente e são facilmente exibidos com o software gratuito Acrobat Reader DC. Disponível em: https://acrobat.adobe.com/br/pt/products/about-adobe-pdf.html. Acesso em: 17 mai. 2015.
} 
de dados digital específico. Mas construir acervos de documentos específicos não é algo completamente estranho à prática da pesquisa histórica: seja por meio de compras (documentos, livros etc.), seja por meio de cópias manuscritas, gravações analógicas ou digitais, fotocópias, fotografias e escâneres, os historiadores, há décadas, formam seus acervos particulares de documentos escritos, orais, imagéticos etc. A diferença é que, no caso dos blogs e sites, o historiador iria além de formar um banco de dados próprio, ele também seria o responsável por realizar um trabalho de "salvamento da fonte", a fim de preservá-la para consultas futuras.

Todas as páginas selecionadas para compor o acervo de fontes históricas da pesquisa foram salvas utilizando-se do recurso de print screen e, em seguida, arquivadas em PDF, com a data do acesso. A partir daí, a maior parte da consulta foi realizada nestes arquivos. Ainda hoje (junho de 2015), todas estão disponíveis na Internet, muito embora algumas já não estejam mais ativas, ou seja, com postagens regulares de novos textos.

Remediada a questão da efemeridade no que se relaciona especificamente a estas fontes selecionadas, entendo que o maior desafio fica por conta de se lidar com as escalas temporais variadas em que cada texto é construído, tempo longo ou muito curto. Bem como a forma com que cada texto é organizado; formas de apresentação, especialmente sobre as relações entre oralidade e escrita, os suportes em que se apresentam, as possibilidades de reelaborações das histórias, das contribuições dos leitores nessa reescrita. Não obstante essas questões mais específicas da escrita e formato das narrativas (que serão descritas a seguir), os demais desafios seguem sendo comuns ao trabalho com textos escritos, independente de sua materialidade ou suporte: situar o lugar social de quem escreve e pra quem se escreve, identificar o conteúdo e como foi organizado, usos e apropriações possíveis do texto pelos leitores etc. Trabalho que exige organização da dispersão e interpretação para permitir que o "documento fale", e, neste processo, não esquecer de realizar a crítica do documento em sua condição de monumento. Enfim, lições básicas e irredutíveis da prática historiográfica. 


\section{Narrativas digitais como ego-documentos}

O arquivamento do eu não é uma prática neutra;

é muitas vezes a única ocasião de um indivíduo se fazer ver tal como ele se vê e tal como ele desejaria ser visto.

(ARTIÈRES, 1998, p. 31)

A partir do século XIX, diários e cartas escritas à mão, em espaços silenciosos e privados da casa, conservados em suportes de papel, foram práticas comuns de confessar, exteriorizar a interioridade, o íntimo. Paula Sibilia (2009, p. 315) chama a atenção que, para escrever estes textos confessionais e para o consequente ato de criar "un yo que es al mismo tiempo autor, narrador y personaje de la propia vida", eram necessários solidão e silêncio. Além disso, esses escritos demandavam "una distancia espacial y temporal con respecto al destinatario de las cartas y a los eventuales lectores de los diários". Com a "era do acesso", porém, as práticas de confessar a intimidade e o formato dos diários se alterariam; no presente estão à vista de todos, nas redes sociais, nos sites pessoais, nos blogs.

Paula Sibilia (2008, p. 29-31) define as novas práticas de comunicação e expressão na Internet, que exibem a intimidade (ou "extimidade") como pertencentes aos gêneros autobiográficos. Compreende-se que as histórias postadas nos blogs são narrativas de si, o que implica pensar num conjunto de questões importantes levantadas por Sibilia, relativas ao caráter de ficção ou não dessas narrativas, de possíveis deslocamentos quanto à "experiência de si como eu" na organização das experiências vividas e relatadas.

Os blogs popularizaram-se a partir do final da década de 1990, sob o formato de um diário virtual, em que uma ou várias pessoas escrevem periodicamente. Eles se multiplicam na Internet como ferramentas de uma narrativa híbrida (misto de diários, crônicas jornalísticas e correspondências), cuja estrutura permite atualizações rápidas a partir de acréscimos de artigos e/ou comentários. Os blogs potencializaram as formas de 
narrar de si e trouxeram mudanças em relação aos formatos tradicionais do passado, como cartas, diários e memórias, por exemplo. Contudo, não são os responsáveis pela produção dos efeitos narrativos do eu e não inventaram a vontade de contar histórias pessoais. Essas disposições da subjetividade existem muito antes das redes sociais, o que ocorre é que, a partir delas, essa necessidade parece se desdobrar sem limites.

Em relação às páginas selecionadas, observa-se que as escritas pessoais são postadas como memórias, no caso em questão, experiências da escolarização desenvolvidas em torno de um tema comum: os exames de admissão ao ginásio. Os textos escritos são híbridos, alternam textos e imagens, tons mais intimistas, pessoais, com trechos mais informativos. Os administradores das páginas, quase sempre também os autores dos textos postados são, em sua maioria, homens. Entre os 16 sites, apenas 4 são administrados por mulheres. Os contadores de histórias sobre os exames de admissão são, hoje, professores/as aposentados/as, profissionais liberais, funcionários públicos, também são escritores ou poetas, advogados e há um pastor (Igreja Evangélica Congregacional) ${ }^{9}$. Moram em diferentes cidades do Brasil e a maioria das memórias constrói-se a partir desse recorte espacial, como por exemplo: São Paulo/SP, Campos do Jordão/SP, Catanduva/SP, Belo Horizonte/MG, Palmeira/PR, Santa Maria/RS, Óbidos/PA, Macau/RN, Crato/CE, Delmiro Gouveia/AL, dentre outras.

Os administradores, colaboradores e/ou comentaristas (escritores/autores dos textos) são todos adultos, possivelmente - guardados alguns distanciamentos caberiam na descrição de "imigrantes digitais" , posto que suas lembranças organizam-

\footnotetext{
${ }^{9}$ Esses lugares sociais se sobrepõem, como, por exemplo, professores aposentados que são funcionários públicos, funcionários públicos que não são professores, mas que também são escritores e/ou poetas etc.

10 "Nativos digitais" e "imigrantes digitais" são metáforas que serviriam para descrever o grau de destreza das pessoas com o manuseio das ferramentas da TICs. Os nativos seriam os jovens e crianças nascidos rodeados de telas, teclados e mouses, que têm acesso a um ou a vários dispositivos, como computadores, tablets e celulares desde pequenos e que utilizam sem esforço em sua vida privada e fora da escola, mesmo que ninguém Ihes tenha formalmente ensinado. Usam esses dispositivos para criar, inventar e compartilhar informações com seus amigos de carne e osso ou com seus amigos das redes sociais. Já os imigrantes, seriam os adultos que tiveram uma infância analógica, sem computadores, celulares, Internet. Seus artefatos culturais foram - e seguem sendo, mesmo após o acesso a Internet - produtos tangíveis: os livros, os papéis, as bibliotecas físicas etc. Sua forma de aprender a usar as modernas ferramentas disponíveis é, sobretudo, o ensino formal (CASSANY; AYALA, 2008).
} 
se em torno dos artefatos analógicos com os quais conviveram e demonstram valorizar. Todas as páginas possuem uma estrutura de concepção básica, apresentando a organização padrão disponibilizada pelo desenvolvedor do formato ${ }^{11}$. Os recursos estéticos ficam por conta da cor, tipo e tamanho das letras que se diferenciam nos títulos e legendas. Abaixo essa organização pode ser mais bem observada:

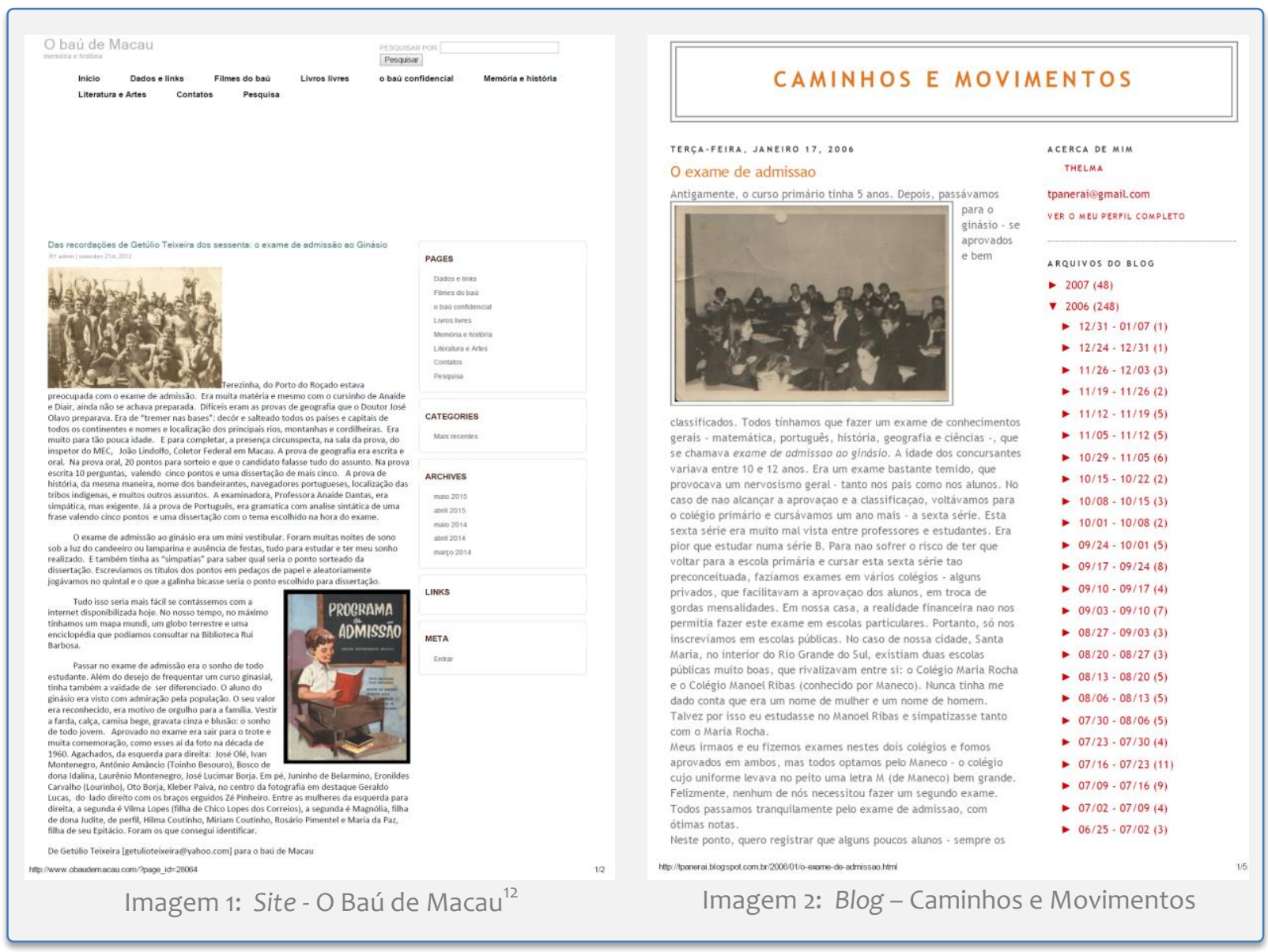

Os textos sobressaem-se nas páginas e, não raro, as histórias vêm acompanhadas de outros vestígios do passado: fotografias do tempo em que os narradores eram jovens, certificados com as notas dos exames, fotografias de ex-professores e colegas, das

11 Diferentes empresas disponibilizam na internet uma série de modelos e manuais passo a passo gratuitamente para que as pessoas interessadas possam criar sua página pessoal em formato de website ou de blog. A criação de um website exige conhecimento mínimo em HyperText Markup Language (HTML), além de necessidade de domínio, hospedagem etc. Já a criação de um blog é de baixa complexidade, requisitando conhecimentos mínimos. Um dos serviços mais populares é o blogspot.com, propriedade da empresa Google, desde 2003, e também o wordpress.com.

${ }^{12}$ Com o objetivo de deixar o texto mais limpo, o endereço completo das páginas citadas, seguido da data de acesso, estará apenas ao final do texto, após as referências. 

se pode observar nas imagens abaixo:

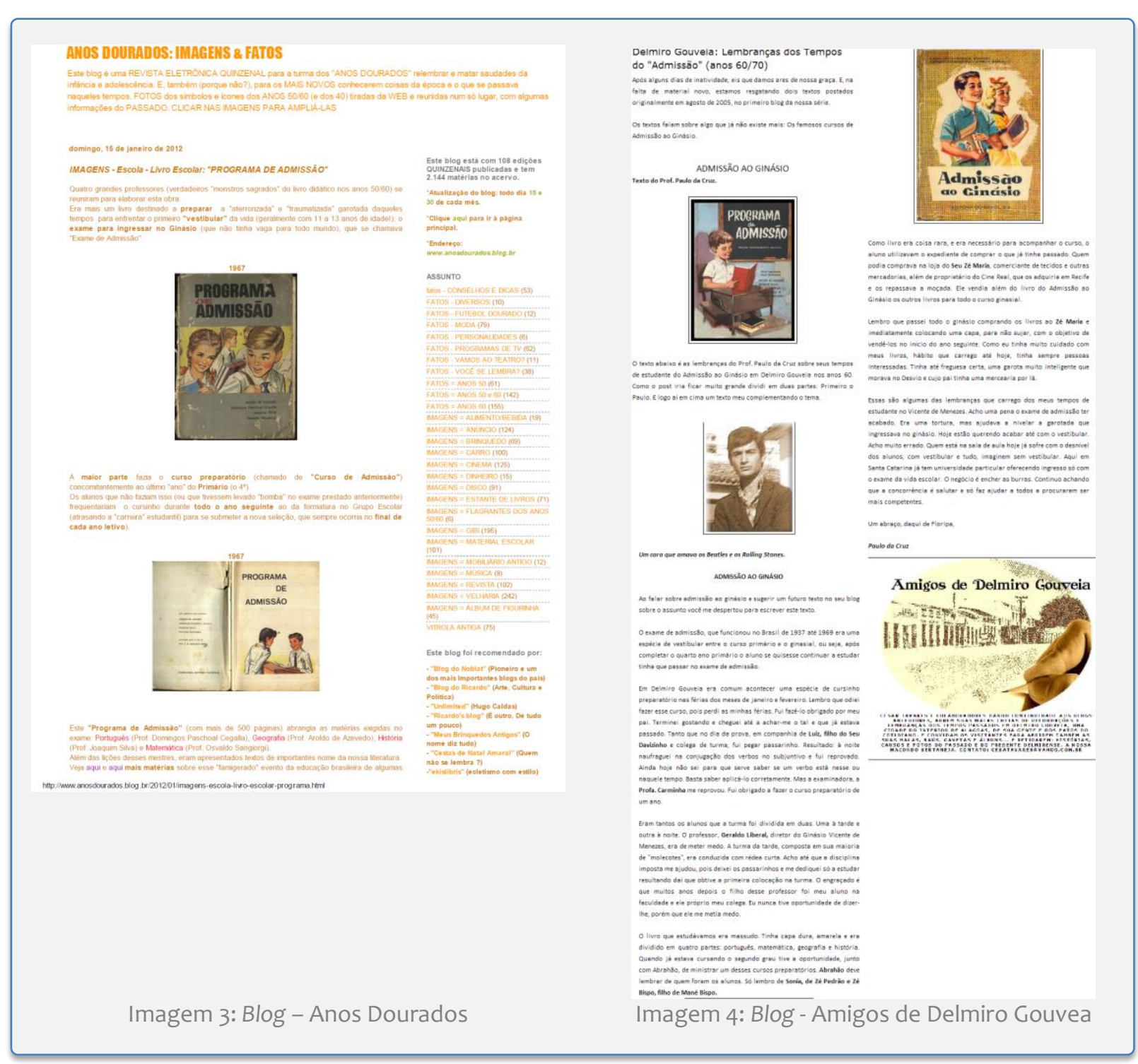

fachadas das escolas, e, com certo destaque, imagens das capas dos livros preparatórios
para os exames que circularam no período de sua vigência. Destaca-se que a maioria dos textos traz capas (também às vezes, frontispícios ou outras páginas) desses livros, como

O professor Paulo da Cruz, além de escrever sobre o curso preparatório e seus professores, posta uma foto da capa do livro e o descreve em seu texto postado no blog Amigos de Delmiro Gouvea, em 15 de maio de 2012: "Tinha capa dura, amarela e era dividido em quatro partes: português, matemática, geografia e história. [...] Como livro era coisa rara, e era necessário para acompanhar o curso, o aluno utilizava o expediente de comprar o que já tinha passado". Antônio Moraes, no blog Sanharol, inicia seu texto 
intitulado "Nos anos 60", de 21 de janeiro de 2013, com a imagem da capa do mesmo livro Admissão ao Ginásio escrevendo: “O meu livro era de pelo menos oitava mão, ou seja, já havia passado por oito antes de mim. Todas as figuras estavam riscadas, bigodes, óculos, até chifres nas fotos havia".

Os comentários postados também compartilham lembranças dos mesmos livros, como o de Graça Cantalino que, em 04 de setembro de 2012, ao comentar o texto de Márcio Lima (publicado no blog maricioonline), escreveu: "Uma lembrança deliciosa do meu livro, lido e relido, passado de mão em mão, como devem ser os livros úteis. Lembro que um colega da minha turma naquela época decorou todos os textos, é sério... ele sabia todos. Qualquer um daqueles poderia ser sorteado na prova. Demais!".

Alguns desses livros alcançaram grande sucesso editorial, muitos deles com sucessivas edições até a década de 1970. Nos blogs, os livros cujas imagens de capa mais aparecem e as que mais são referenciadas nas memórias são dois: o livro assinado por Aroldo de Azevedo, Joaquim Silva, José de Arruda Penteado, José Cretella Jr., e Oswaldo Sangiorgi chamado Programa de Admissão. Publicado pela Cia Editora Nacional, este livro teve, no ano de 1956, duas edições: a primeira com 50.000 exemplares e a segunda com 100.000. A quinta edição, de 1959, teve tiragem de 150.000 exemplares. A pesquisa localizou a $22^{\text {a }}$ edição, publicada em 1970 e uma evidência de reimpressão dessa edição em 1971, ano que os exames foram extintos. E o livro de Aida Costa, Marcius Brandão, Renato Stempniewski e Aurélia Marino chamado de Admissão ao Ginásio. Publicado pela Editora do Brasil S/A, a primeira edição desse livro é de 1952. Em 1958, o livro já estava na $180^{\mathrm{a}}$ edição. O exemplar localizado na pesquisa não traz informação quanto à tiragem, mas até 1969 houve 548 edições da obra. ${ }^{13}$

As escritas de si postadas em diários online apresentam diferenças sensíveis em relação às tradicionais formas de confessar o eu. Essas diferenças dizem mais respeito à forma e à estrutura de como as escritas são organizadas e veiculadas e não fundamentalmente sobre a necessidade de narrar a vida, de fixar o tempo passado,

\footnotetext{
${ }^{13}$ Gostaria de registrar meus agradecimentos à professora Maria Helena Câmara Bastos que generosamente me emprestou diferentes edições dos livros Admissão ao Ginásio e Programa de Admissão, além de outros menos conhecidos, pertencentes a seu acervo pessoal. Também à professora Maria Teresa Santos Cunha pela disponibilização da $12^{\circ}$ edição do livro Programa de Admissão.
} 
conservando dimensões da vida para o futuro. "É, em primeiro lugar, para si que se escreve um diário: somos nossos próprios destinatários no futuro" (LEJEUNE, 2008, p. 261). No passado, além de uma escrita para si, os diários também apelavam para uma leitura posterior. A menos que o escritor tivesse coragem de destruí-lo, mesmo secreto, o diário servia para a "transmissão de algum alter ego perdido no futuro, ou modesta contribuição para a memória coletiva" (LEJEUNE, 2008, p. 262). No presente, a questão é que em se tratando dos diários virtuais, a leitura não se restringe à posteridade, há um apelo ao outro que é imediato; do contrário, para que serviriam os contadores de visitantes nesses sites? Isso porque a "Internet fornece um dispositivo que concilia, numa mesma experiência, o recolhimento e o retorno ao outro [...], os diaristas se leem entre si" (LEJEUNE, 2008, p. 343). Encontrei algumas referências que confirmam essa peculiaridade. A postagem do texto “Admissão ao Ginásio nos anos 60", em 07 de julho de 2012, escrito por Wilma S. Legris (a administradora do blog IECC-Memórias) traz as capas de dois livros, informando que haviam sido postados no blog Anos Dourados, em 28 de fevereiro de 2009 e em 15 de janeiro de 2012, respectivamente. Também é comum que um blog recomende a leitura do outro e que cada blog informe quem os recomendou.

Nos diários tradicionais a base é a data, "o primeiro gesto do diarista é anotá-la acima do que vai escrever" (LEJEUNE, 2008, p. 260). Dessa forma, a escrita se organiza do mais antigo para o mais recente. As narrativas digitais também privilegiam a data que é imediatamente seguida de um título e do respectivo texto. Mas ao contrário dos diários tradicionais, a organização prioriza a entrada mais recente em relação a mais antiga. Os textos mais antigos vão ficando para trás e, ainda que permaneçam acessíveis, vão perdendo a visibilidade perante os leitores.

As escritas dos blogs, como parte da história da cultura escrita do tempo presente, precisam ser analisadas considerando-se as funções e usos relacionados às práticas da escrita e de leitura (GOMÉZ, 2002; 2003; 2012). Em relação aos textos analisados, observase que uma de suas principais funções é a de "arquivamento do eu" (ARTIÈRES, 1998, p. 31), com vinculações irredutíveis tanto com a publicização do privado e do íntimo quanto com a conservação e monumentalização de determinados acontecimentos passados, alçados à condição de memória, de algo que não deve ser esquecido. Exemplo disso é o 
blog IECC-Memórias dedicado ao Instituto de Educação Caetano de Campos, de São Paulo. A abertura da página indica no alto que o blog Caetano de Campos é uma "publicação de memórias: 1957 a 1968, tendo o IECC como pano de fundo num Brasil em mutação; fotos; textos; trechos do livro; contactos; reações e troca de ideias entre os ex-alunos." Os textos postados são uma tentativa de interditar o esquecimento desta tradicional escola paulista, bem como de alguns dos sujeitos que a frequentaram. Mas também, do mesmo modo, é uma forma de a administradora, Wilma S. Legris, dar a ver e a ler versões dela, de seu passado, de seu presente, de um cotidiano e história de vida inventados, conquanto não sejam mentiras. Esse blog representa as combinações possíveis entre invenções de si, memória e esquecimentos, em textos híbridos que combinam oralidade, escritura, palavra e imagens, realidades vividas e imaginadas. Quando Wilma se dirige aos leitores, é como se ela estivesse falando com amigos próximos, o tom é coloquial: "Então vou fazer aqui o meu retrato escrito e deixar algumas fotos para me apresentar aos novos bloguistas e para que aqueles que me conhecem superficialmente possam travar um conhecimento mais íntimo, mais próximo". O texto trata de sua trajetória de vida, traz fotos urdindo a dispersão organizando-a cronologicamente; enquanto faz isso, dá sentido a sua própria existência.

Todo o texto escrito é escrito para alguém, possui um destinatário. Em relação aos textos analisados, observa-se que eles destinam-se primeiramente à rede de sociabilidades na qual se insere o autor, seus amigos e, em alguma medida, alguns parentes. São eles os primeiros leitores, às vezes os que primeiro comentam e que contribuem com outros textos. Além desse grupo mais próximo, os textos são endereçados a conhecidos do passado numa tentativa de recuperar/reconstruir velhos laços. Isso porque as referências privilegiadas (seja por meio de fotografias, citações de nomes e acontecimentos específicos), fazem alusão a pessoas que, de alguma forma, participaram do passado desse narrador/autor, seja porque estavam lá, seja porque acompanharam suas histórias de modo mais próximo, mesmo que não as tenham experienciado. Claro que os desconhecidos são muito bem-vindos, mas não qualquer desconhecido, e sim aqueles que compartilham o gosto pelo passado, pelas memórias. Por isso que os administradores de blogs compartilham-se mutuamente, recomendando 
leituras, informando endereços de outros blogs. Os leitores apresentam-se, aí, em níveis variados, modulados por distâncias e proximidades em relação a quem escreve.

Os textos principais são bem escritos, diferenciam letras maiúsculas de minúsculas, possuem frases e parágrafos bem estruturados com pouco ou nenhum erro ortográfico ou de concordância. Diferentemente dos comentários, espaços mais informais da escritura, que emprestam mais traços da fala e que podem vir escritos sem a preocupação com a pontuação e até mesmo podem vir grafados no seu todo em letras maiúsculas. Mas, nesses mesmos blogs, observa-se que os textos principais ou os comentários podem até trazer algumas palavras grafadas de modo incorreto ou algumas frases com ausência ou pontuação inadequada, mas são expressivamente escritos sem o recurso da abreviação. A abreviação também parece ser um recurso dos jovens, os "nativos digitais".

Considero importante que a leitura dessas diferenças seja norteada por reflexões sobre marcadores sociais relacionados à geração, gênero, classe etc. Em razão dos limites desse artigo, não poderei dar conta de todos aqui, mas, em se tratando de geração, por exemplo, pode-se observar que esses narradores gostam de escrever, evidenciam saber utilizar corretamente os códigos tradicionais baseados na leitura e escritura. Eles não representam riscos para um "futuro sem palavras", aludidos em algumas análises sobre crianças, adolescentes e a cultura escrita na Internet. Castillo Gómez (2004a) chama a atenção para esse risco à medida que crianças e jovens, mesmo sem dominar a escrita e a leitura, integram redes sociais na Internet, utilizando-se de símbolos, abreviaturas e imagens no lugar de palavras. Mas como esse historiador também acrescenta, 0 problema "não está na tecnologia, mas no uso que façamos dela. E é aqui que tem cabimento um dos receios levantados [...] que a hegemonia contemporânea das novas tecnologias nos leve a substituir os investimentos na leitura e na cultura escrita pelos multimilionários planos de alfabetização informática" (2004b, p. 70).

Os adultos que escrevem nessas páginas dominam os códigos de leitura e escrita e os usos que fazem desses espaços são muito diferentes dos usos que fazem crianças e jovens. Os autores/narradores das histórias vinculam-se muito fortemente ao passado, às memórias. Essa característica é uma marca geracional importante. Baseada em diferentes 
estudos, Leonor Arfuch (2014, p. 30) analisa que os jovens buscam a aprovação, reivindicam o pertencimento a uma determinada comunidade, setorizada, configurada de acordo com certas pautas de distinção. Os jovens possuiriam uma identidade online que se atualiza todo o tempo, conformando parte do ser, da existência e da experiência em um presente, que talvez revele um sintoma de solidão globalizada, ligado a uma fragilidade afetiva que envolve, ao mesmo tempo, o temor à negação diante de tanta exposição. Já os adultos, por sua vez, usam os diários como mais uma estratégia de vinculação com o passado, suas escritas estariam mais próximas de uma "recuperação proustiana do tempo perdido". O espaço virtual aparece como possibilidade de reencontro de redes e amigos, lugar de buscas não isentas de nostalgia e que, também para eles, serviriam para explorar novas identidades e reinvenções de si, “después de 'las vueltas de la vida', sus fracasos o sus frustraciones y la consecuente tentación de realizar el "podría haber sido"”.

Chama a atenção que os textos principais são sempre de autoria dos administradores. Eles pautam os temas das memórias, escolhem o que não deve ser esquecido. Os outros textos que respondem a "essa interpelação" inicial são postados por leitores que contribuem para a história e existem também os comentários que, tanto acrescentam coisas novas à narrativa como também corrigem alguma informação ou simplesmente agradecem e/ou elogiam o texto. Em relação a essa reescrita, pode-se citar, por exemplo, a história do professor Paulo da Cruz (Blog - Amigos de Delmiro Gouveia), seguida do texto de César Tavares (administrador do blog). Ambos os textos tiveram 14 comentários $^{14}$. Selecionei três desses comentários, sendo o último do professor Paulo da Cruz, autor de um dos textos postados, que aproveita para dar sequência a sua história:

O tempo passa, e, com ele caminhamos todos juntos, sem parar, nossos passos pelo chão vão ficar... Em 1973 comecei a estudar no grupo escolar Francisca rosa da costa, na época nós morávamos vizinho ao Paulo Roberto (popular Beto de Dolores) bem próximo ao sindicato dos tecelões onde existia o tão temido curso do Admissão. O meu pai era um comerciante e sempre falava desse tal curso para o ingresso ao GVM, e que os filhos dele sempre parava de estudar neste paredão, mas ao mesmo tempo ele elogiava o curso e condenava os filhos por não ter

\footnotetext{
${ }^{14}$ A fim de preservar a diferença entre os comentários e os textos, não foram realizadas correções quanto à forma da Língua Portuguesa nos excertos dos blogs e sites.
} 
interesse no estudo. Graças a Deus na minha época não existia esse paredão, e, sim uma disciplina um pouco rígida, onde os livros didáticos já faziam parte do roteiro escolar. Lembro-me como se fosse hoje dos protagonista do meu primeiro livro da primeira série, que são: Fernando, Silvinha e Benedito. Quanto a sala de aula, recheadas mais ou menos de quarenta analfabetos, à professora Lenilda se virava nos trinta em passar conteúdo das matérias que faziam parte do currículo da época. Saudades, saudades...(Reginaldo de Bastião, 16 de maio de 2012, 13h11).

Fiz meu curso de admissão no Ginásio Paulo Afonso e o livrão adotado era o que está na primeira ilustração. Não sei se estou me confundindo, mas me parece que esses livros PROGRAMA DE ADMISSÃO traziam algumas figuras com paisagens campestres, de cidades, etc, para que baseados no que víamos fizéssemos uma composição. Aí, o que valia mesmo era a criatividade de cada um. (Paurílio, 19 de maio de 2012, 11ho4).

Falar sobre o "Admissão ao Ginásio" leva a um forte retorno ao passado. O curso tinha a sua importância, pela revisão que fazia dos assuntos "aprendidos" nos quatro anos do curso primário. Funcionava como uma espécie de vestibular, tanto que após o quarto ano bastava se submeter ao exame e, caso aprovado, ingressar no ginásio. Era comum haver um cursinho preparatório, no intervalo entre o encerramento das aulas no grupo escolar e o dia do exame. Eu fiz esse cursinho e tentei entrar logo no ginásio. Não obtive êxito (felizmente) no exame. Se tivesse sido aprovado provavelmente minha vida teria tomado outro rumo. Fui obrigado a cursar o admissão durante todo um ano. Minha turma era vespertina. Tinha outra turma à noite. Por aí se vê quantos estavam tentando ingressar no ginásio. Isso foi durante o ano de 1971. Faz um tempão. O livro usado, pelo que lembro, era semelhante, se não o mesmo, ao que aparece na foto postada por você. Não está fácil encontrá-lo nos dias de hoje. Uma busca em sebos pela Internet mostrou apenas três exemplares disponíveis, alguns em péssimo estado de conservação. Quanto ao preço, está nas alturas, por conta da sua raridade. Resolvendo o mistério, quanto a identidade da compradora dos meus livros, posso dizer que as opções que você listou a incluem. Era Risalva Oliveira, filha do seu Rosalvo. Os meus livros, graças aos cuidados que recebiam de minha parte, eram disputados. Normalmente em setembro já começava a ser sondado quanto a possibilidade de realizar a sua venda, ao final do ano. A venda de livros era comum em DG naquela época. Além de ajudar a comprar os livros para o ano seguinte evitava que os antigos ficassem sem utilidade, a falta de um irmão mais novo na fila de espera. Livro escolar é para ser usado, quanto mais se usa mais ele cumpre seu papel de disseminador de conhecimentos. (Paulo da Cruz, 29 de julho de 2012, 09h15). 
Observa-se que os textos iniciais foram reescritos por meio de acréscimos. A cultura escrita na esfera digital caracteriza-se tanto pelas abreviaturas constantes - de tempo, de palavras, de acontecimentos - quanto pela rapidez com que um texto pode ser lançado, transmitido, recebido, apropriado. Percebe-se também, nessa intersecção entre a aceleração do tempo e a necessidade de lembrar, um borrar de fronteiras entre escritores e leitores. Nesses blogs, escritores e leitores participam da reescrita do texto; percebe-se aí, conjuntamente, fragmentação e modificação de ideias e percursos narrativos. Tais reescritas são novamente lançadas em dias diferentes e o que temos é a uma rede de conexões múltiplas, com suas fugacidades e a facilidade com que um texto pode alterar-se, transformar-se, reestruturar-se ou desaparecer, inclusive para sempre. São autores e leitores que escrevem, lêem e reescrevem em intervalos de tempos variados, configurando outras relações entre narrativa e tempo, entre o mundo do escritor e do leitor, entre o oral e o escrito.

Para Viñao Frago (2002, p. 355), a escrita digital empresta traços da fala: espontaneidade, iminência e imediatez e, ao fazê-lo, debilita o distanciamento tradicionalmente associado aos atos da escrita e da leitura, assim como a separação no tempo da produção de um texto e sua apropriação por leitores determinados em épocas diferentes. Acompanhamos esse historiador, que é nessa intersecção entre oralidade e escrita que estão se produzindo, num ritmo acelerado, as mutações mais importantes no âmbito da cultura e comunicação escritas.

Para além desses pontos de contato entre a escrita e a oralidade, as narrativas digitais apontam também para deslocamentos sobre a percepção das temporalidades. $O$ efêmero ganha dimensões complexas quando também se entrecruza com o trabalho da memória, com escritas e testemunhos de si. As discussões de Lejeune (2008) sugerem uma ampliação dos trabalhos com a memória a partir das escritas digitais. Nesse entrecruzamento, memória e arquivo, clássicos pilares do "espaço biográfico" (ARFUCH, 2014) dissimulam a temporalidade efêmera do espaço digital, dando mostras que nele também não se quer perder, não se quer esquecer. 


\section{Narrativas digitais e a configuração das subjetividades}

Aprendemos a convertirnos en el narrador de nuestra propia historia sin que nos convirtamos por entero en el actor de nuestra vida. (RICOEUR, 2006, p. 21)

Ricoeur (2006) define a subjetividade como identidade narrativa. Para ele, a subjetividade não é nem uma série incoerente de acontecimentos nem uma substância imutável ou inacessível do devir. Cada sujeito reinterpreta a identidade narrativa que lhe constitui a partir dos relatos propostos pelo mundo social e cultural em que habita. Ele defende que essa autocompreensão apresentaria os mesmos traços de tradição que a compreensão de uma obra literária, por isso que aprendemos a nos converter em narradores de nossa própria história sem que nos convertamos completamente em autores de nossa vida. Ao narrar nossa própria vida, aplicaríamos a nós mesmos o conceito de vozes narrativas que constituem as intrigas das epopeias, das tragédias, dos dramas e das novelas. Nessas obras, o autor se disfarça de narrador para escrever as histórias que lemos e, nós, na condição de narradores de nós mesmos, só podemos imitar essas vozes narrativas sem chegar a nos converter em autores. "Esta es la gran diferencia entre la vida y la ficción. En este sentido, es realmente cierto que la vida se vive y que se narra la historia" (RICOEUR, 2006, p. 21). Essa diferença entre vida e ficção poderia ser suprimida parcialmente por meio de variações imaginativas quando tentamos alcançar uma compreensão narrativa de nós mesmos e usamos para isso referências das tramas às quais temos acesso em nossa cultura. A identidade narrativa estaria situada em meio a esse processo de se reinventar, de se reinterpretar como história.

As narrativas digitais selecionadas tratam de memórias, de passados tornados presentes sobre os exames de admissão ao ginásio. Mas, para além dos exames, os textos tratam primeiro de percursos individuais de sujeitos que reescrevem a si mesmos quando escrevem essas histórias. O professor Paulo Cruz, escreveu o texto intitulado “Admissão ao Ginásio”, no blog Amigos de Delmiro Gouveia, em 15 de maio de 2012: 
Em Delmiro Gouveia ${ }^{15}$ era comum acontecer uma espécie de cursinho preparatório nas férias dos meses de janeiro e fevereiro. Lembro que odiei fazer esse curso, pois perdi as minhas férias. Fui fazê-lo obrigado por meu pai. Terminei gostando e cheguei até a achar-me o tal e que já estava passado. Tanto que no dia da prova, em companhia de Luiz, filho do Seu Davizinho e colega de turma, fui pegar passarinho. Resultado: à noite naufraguei na conjugação dos verbos no subjuntivo e fui reprovado. Ainda hoje não sei para que serve saber se um verbo está nesse ou naquele tempo. Basta saber aplicá-lo corretamente. Mas a examinadora, a Profa. Carminha me reprovou. Fui obrigado a fazer o curso preparatório de um ano. Eram tantos os alunos que a turma foi dividida em duas. Uma à tarde e outra à noite. O professor, Geraldo Liberal, diretor do Ginásio Vicente de Menezes, era de meter medo. A turma da tarde, composta em sua maioria de "molecotes", era conduzida com rédea curta. Acho até que a disciplina imposta me ajudou, pois deixei os passarinhos e me dediquei só a estudar resultando daí que obtive a primeira colocação na turma. O engraçado é que muitos anos depois o filho desse professor foi meu aluno na faculdade e ele próprio meu colega. Eu nunca tive oportunidade de dizer-lhe, porém que ele me metia medo. O livro que estudávamos era massudo. Tinha capa dura, amarela e era dividido em quatro partes: português, matemática, geografia e história. Quando já estava cursando o segundo grau tive a oportunidade, junto com Abrahão, de ministrar um desses cursos preparatórios.

Antônio Moraes escreveu no blog Sanharol, texto intitulado "Anos 60", publicado em 22 de janeiro de 2013:

Naquela época, até o final dos anos 60, pelos menos, havia vestibular para entrar no Ginásio. Era comum a criançada do quarto ano primário fazer uma espécie de cursinho visando preparar-se para o exame de Admissão. O meu livro era de pelo menos oitava mão, ou seja, já havia passado por oito antes de mim. Todas as figuras estavam riscadas, bigodes, óculos, até chifres nas fotos haviam. Minha querida e inesquecível professora Dona Iracy Bezerra de Morais preparava nossa turma para um exame de segunda época para o preenchimento de cinco ou seis vagas restantes oferecida pelo Colégio. Fui aprovado e assim iniciei o antigo curso colegial em 1965.

\footnotetext{
${ }^{15}$ Cidade do interior de Alagoas.
} 
Thelma, no blog Caminhos e Movimentos, escreveu em 17 de janeiro de 2006:

Antigamente, o curso primário tinha 5 anos [..]. Todos tínhamos que fazer um exame de conhecimentos gerais - matemática, português, história, geografia e ciências -, que se chamava exame de admissão ao ginásio. A idade dos concursantes variava entre 10 e 12 anos. Era um exame bastante temido, que provocava um nervosismo geral - tanto nos pais como nos alunos. No caso de não alcançar a aprovação e a classificação, voltávamos para o colégio primário e cursávamos um ano mais [...]. Em nossa casa, a realidade financeira não nos permitia fazer este exame em escolas particulares. Portanto, só nos inscrevíamos em escolas públicas. No caso de nossa cidade, Santa Maria, no interior do Rio Grande do Sul, existiam duas escolas públicas muito boas, que rivalizavam entre si: o Colégio Maria Rocha e o Colégio Manoel Ribas (conhecido por Maneco). Nunca tinha me dado conta que era um nome de mulher e um nome de homem. Talvez por isso eu estudasse no Manoel Ribas e simpatizasse tanto com o Maria Rocha. Meus irmãos e eu fizemos exames nestes dois colégios e fomos aprovados em ambos, mas todos optamos pelo Maneco - o colégio cujo uniforme levava no peito uma letra $M$ (de Maneco) bem grande. Felizmente, nenhum de nós necessitou fazer um segundo exame. Todos passamos tranquilamente pelo exame de admissão, com ótimas notas. Neste ponto, quero registrar que alguns poucos alunos - sempre os mais inteligentes e preparados não completavam os 5 anos de primário, como a esmagadora maioria. Estes alunos, quando terminavam a $4^{\mathrm{a}}$ série, inscreviam-se para o fazer 0 exame de admissão ao ginásio. Eram os que "pulavam o $5^{\circ}$ ano". Passavam diretamente da $4^{\mathrm{a}}$ série do primário, para o ginásio. Só os que realmente estavam muito preparados obtinham aprovação e classificação no ginásio, porque, teoricamente, $05^{\circ}$ ano era o ano de revisar tudo o que se tinha aprendido no primário. Era o ano de preparação para o exame de admissão. Um dos poucos alunos que conseguiu esta façanha foi o meu irmão, Jayme. Ele conseguiu esta proeza histórica e reconhecida por todos! Naquela época, com a idade que tínhamos e no contexto em que vivíamos, "pular o $5^{\text {"l }}$ era o máximo! [...] Este irmão foi o primeiro que entrou no Maneco. Levou com ele a fama de inteligente. Em pouco tempo, as professoras já o queriam e o cuidavam com especial atenção. Anos mais tarde, entrou o segundo irmão, Felipe, que sempre foi o mais disciplinado, estudioso e meigo, e que até hoje cativa a gregos e troianos. Era um aluno nota dez, daqueles que todos os professores amam ter em suas classes. Quando entrei eu, já tinha um sobrenome conhecido no colégio e, obviamente, as expectativas docentes já estavam delineadas no que se referia a mim. Mas não respondi a estas expectativas, infelizmente. Eu não era tão inteligente, nem era a mais disciplinada, nem a mais simpática e nem a mais fácil de tratar. A verdade é que eu não possuía o brilho e o carisma de meus irmãos. 
Nessas narrativas, expressões como “antigamente”, “naquela época”, “era comum" situam as lembranças num tempo passado, e exemplos de como a escola ou os exames são no presente demarcam um período de mudanças, de passagem do tempo na qual o presente apresenta-se como pior em relação a um passado, muito melhor. A marca pessoal está gravada e dá o tom nesses escritos: “odiei fazer o curso [...] me dediquei só a estudar” (Paulo da Cruz); “o meu livro era pelo menos de oitava mão” (Antônio Moraes); “Eu não era tão inteligente, nem era a mais disciplinada, nem a mais simpática e nem a mais fácil de tratar. A verdade é que eu não possuía o brilho e o carisma de meus irmãos" (Thelma). Outra questão instigante é pensar que as memórias desses ex-estudantes tornadas presentes em diferentes narrativas, em quase nada se relacionam com os resultados dos estudos que apontam para o caráter seletivo e altamente excludente dos exames de admissão e do Secundário no período (NUNES, 2000; PESSANHA; DANIEL, 2002; MINHOTO, 2007; 2008).

O professor Paulo da Cruz, Antônio Moraes e Thelma fizeram os exames em tempos e lugares diferentes, mas suas lembranças possuem traços comuns: a pressão para passar nos exames, a consequente ansiedade em relação ao volume de conteúdos que precisavam estudar, as dificuldades desse tempo e a atribuição de importância de ser aprovado nos exames, o que dá a ler a constituição de si como vencedores. Têm em comum também a necessidade de organizar, na trama do escrito, a trama da vida: o antes, o depois, as ações, os sofrimentos, as vitórias, enfim, as peripécias que dão sentido à narrativa e, ao mesmo tempo, dão sentido a sua existência.

Para Ricoeur (2010), é a narrativa que torna acessível a experiência humana do tempo, e o tempo, por sua vez, só se torna humano por meio da narrativa. Pertencemos à “espécie dos narradores" porque narrar configura a nossa existência. Interpretamos a nós mesmos através de histórias, ou melhor, operações de mimesis "mediante as quais a experiência prática dá a si mesma obras, autores e leitores" (RICOEUR, 2010, p. 95). Os textos publicados nessas páginas são exemplos de vinculações estreitas entre obras, autores e leitores. Por vezes, não há como separar a obra do autor e autor do leitor. As memórias sobre os exames de admissão são apenas mais um meio encontrado para que cada um fale de si, organize e integre a dispersão dos elementos de sua vida, os vários 
níveis temporais, as idas e vindas numa narrativa organizada cronologicamente, numa sucessão de acontecimentos, numa história.

Em relação às escritas de si na Internet, convém considerar nas análises os possíveis deslocamentos em relação à "experiência de si como eu", ou melhor, "à condição de narrador do sujeito" (SIBILIA, 2008, p. 31). Essas reflexões colocam desafios sobre a significação e interpretação do tempo pelos sujeitos do presente, da significação da sua existência, do que é público ou privado quando se trata da intimidade. Essas mudanças podem ser percebidas nas narrativas digitais? Deve-se considerar aí a dimensão do descontínuo que a leitura na tela implica. Tal leitura constitui uma das "revoluções" da cultura escrita: transformar hábitos e percepções pela via da textualidade eletrônica.

Compreende-se que as narrativas digitais podem e devem ser pensadas a partir dos estudos de Paul Ricoeur (2007; 2010), ou seja, como efeitos de sentido que descrevem e representam as ações, os sujeitos e os tempos e configuram a existência humana. A narrativa possui dinamismo integrador que transforma dispersão e incidentes aparentemente não conexos numa história una e completa, passível de ser interpretada, reconfigurada pelo leitor.

Neste trabalho, as memórias foram lidas como representações do passado (RICOEUR, 2007), que podem ter sido tornadas presentes por uma necessidade de se ancorar as experiências da vida diante de um presente alargado e hipertrofiado, resultante de um regime de historicidade presentista ${ }^{16}$. Mas que também apenas respondem na contemporaneidade, com os recursos disponíveis neste tempo, a uma velha necessidade que diz respeito às práticas de escritas de si: necessidade de fixar o passado e também apreender o futuro, necessidade de tomar distância em relação a si próprio, necessidade de arquivar a própria vida, de testemunhar, de se inventar e

\footnotetext{
16 Para François Hartog (2013, p. 28) um regime de historicidade pode ser compreendido a partir de duas acepções, uma mais restrita "como uma sociedade trata seu passado e trata do seu passado" e uma mais ampla que "serviria para designar a modalidade de consciência de si de uma comunidade humana". Acompanhando as análises de Reinhart Koselleck, Hartog identifica três regimes de historicidade distintos: história como mestra da vida, que remonta a Cícero, hegemônico até pelo menos o século XVIII e na qual a relação entre passado e futuro é regrada pelo passado; regime moderno de historicidade, instalado entre o final do século XVIII e o início do século XIX (caberia ao futuro esclarecer o passado); e, a partir de 1989, o presentismo instalaria outra ordem do tempo em que o presente hipertrofiado é, em si mesmo, seu próprio horizonte, sem futuro e sem passado ou, gerando no presente o passado e o futuro de que necessita.
} 
reinventar. Num belo artigo sobre blogs escritos por mulheres, "De navegar e de navegantes", Zahide Muzart (2000, p. 189) finaliza afirmando: “Os diários íntimos, na internet, perderam o segredo e a intimidade, mas continuam a ser o registro do efêmero e do descontínuo no tempo".

\section{Algumas notas a guisa de (in) conclusão}

Já se falou que o homem é um animal simbólico, outros dizem que é um ser lúdico, outros o definem como "homo faber" ou "homo economicus", enquanto outros afirmam que é um ser que pensa. Mas pode-se dizer também que o que nos caracteriza universalmente é que somos seres que narram sua própria história. Assim como na natureza há os roedores e os herbívoros os humanos pertencem à espécie dos narradores. Narram oralmente, narram por escrito, narram pelo teatro, narram pelo cinema, narram por cores e volumes, narram pela dança, narram conversando na esquina, narram pelos jornais, narram fofocando por telefone e até por e-mail não fazem senão narrar. (SANT'ANNA, 2004, p. 2)

O presente texto tratou da necessidade quase que irrenunciável de narrar que os seres humanos possuem. Essas histórias foram pensadas como escritas de si, e, dessa forma, não foram tomadas nem como verdades e nem como ficções, mas sim como narrativas que integram por meio de referencialidades mútuas aspectos da vida vivida e da imaginação, da ficção. No sentido de que as escritas de si contêm aspectos do vivido, do que se imagina ter vivido, do que se queria ter vivido... Leonor Arfuch (2014, p. 29) lembra que nenhum relato escapa à ficcionalização, mesmo que se estabeleça o pacto autobiográfico, segundo a clássica definição de Lejeune (2008), mesmo que se assuma no eu a "ilusória unidade do sujeito", o narrador de si se constrói como um personagem numa clara distância do eu empírico.

Analisar histórias publicadas em blogs exige, claro, atenções metodológicas e teóricas específicas, afinal estamos tratando "de novas modalidades de construção, publicação e recepção dos discursos históricos" (CHARTIER, 2009, p. 59). Contudo, penso que os desafios implicados na vastidão quase sem limites de fontes documentais que a Internet disponibiliza bem como sua análise, podem ser equacionados com a 
metodologia e teoria da história disponíveis (claro que, mais do que nunca, com o necessário diálogo interdisciplinar). Recortes sempre serão necessários, não importa o tamanho do arquivo e se ele é físico ou digital. Uma pesquisa histórica que possui perguntas pertinentes relativas ao seu objeto e problemas certamente determinará os documentos que melhor permitam a abordagem pretendida. Quanto melhor for a qualidade da pergunta e definição do objeto, menos penoso será selecionar as fontes mais pertinentes. Selecionadas as fontes, deve-se também escolher a metodologia adequada para analisar o documento, segundo sua materialidade e suporte. A metodologia ajudará a refazer as perguntas, qualificá-las. E tal qual a qualquer outra pesquisa histórica, as inteligibilidades, as possíveis respostas, explicações “devem ser buscadas onde sempre estiveram: na boa e antiga teoria da história. Aí se agrupam conceitos capazes de pensar abstratamente os problemas metodológicos gerados pelo fazer histórico." (FERREIRA; AMADO, 1998, p. xvi).

Nos últimos anos, pesquisadores de diferentes áreas têm se debruçado sobre as mídias digitais atentos às mutações nas relações sociais, culturais e psicológicas dos sujeitos individuais e coletivos. São inegáveis as possibilidades de estudos abertas por esses recursos para a escrita de uma história do tempo presente, mas não somente. Trabalhos como o de Robson Fonseca Simões (2012), Pedro Eurico Rodrigues (2012) e Camila Guimarães Dantas (2008) informam como os tempos em que se inscrevem as ferramentas disponíveis na Internet (re)significaram a relação que os sujeitos mantêm com a escrita e a leitura e com os demais usuários que compartilham as mesmas redes ou comunidades sociais. Destacam ainda o redimensionamento da memória a partir das novas formas de registro do passado, que implica outros olhares não apenas sobre a história da cultura escrita, mas também sobre as formas de reelaboração da memória no presente.

Como não poderia deixar de ser, a preocupação com o presente e com a memória operou mudanças substantivas na escrita da história. Construção cultural, o tempo presente determina novas relações com o passado e expectativas em relação ao futuro (KOSELLECK, 2006, p. 16). Essa abordagem impõe novas formas de pensar e representar o passado e seus usos, bem como a construção dos acontecimentos e a 
institucionalização de algumas memórias em detrimento de outras. Esse processo comporta o estabelecimento de novas relações também em relação à memória. Nas palavras de Paul Ricoeur (2007, p. 108) as lembranças distribuem-se "em arquipélagos, eventualmente separados por abismos". O desafio é analisar as narrativas como lugar das lembranças no plural e da memória no singular, como estratégia de diferenciação e de continuidade.

Entendo que as análises apresentadas estão sujeitas a revisões e outras interpretações, especialmente considerando-se que lidamos com documentos efêmeros e bastante singulares. Na condição de historiadora, enfrento uma dupla dificuldade: a primeira reside no exercício de se pensar esses suportes digitais e seus conteúdos como fontes históricas, especialmente no que se refere às questões relativas ao seu arquivo e inscrição como documento/monumento (LE GOFF, 2003). A segunda advém das armadilhas de se generalizar sobre o particular, posto que é inegável a singularidade de cada narrativa pessoal. Apensar dessas dificuldades, penso que a incorporação de tais suportes à operação historiográfica pode contribuir para os estudos sobre a história da cultura escrita no presente, especialmente no que diz respeito as suas formas de produção, veiculação e apropriação. Na condição de escritas de si, são fontes inigualáveis para se refletir sobre a dimensão subjetiva do passado - neste caso, operações de escolhas, silenciamentos e interpolações sobre a experiência da escolarização - a partir de uma memória ao mesmo tempo individual e coletiva sobre os exames de admissão ao ginásio. De igual maneira são fontes para se pensar nossa condição de "hombres-relato" (RICOEUR, 2006), sujeitos que não separam a vida da necessidade de narrar.

\section{Referências}

AMELANG, James S. Presentación - Dossier: De la autobiografia a los ego-documentos: un fórum abierto. Cultura Escrita \& Sociedad, n. ${ }^{\circ}$ 1, p.17-18, sep./2005.

ARFUCH, Leonor. De la subjetividad en el lenguaje (digital). In: OSWALD, Maria Luiza Magalhães Bastos; COUTO JR., Dilton Ribeiro; WORCMAN, Karen (orgs.). Narrativas digitais, memórias e guarda. Curitiba/PR: Editora CRV, 2014, p.27-40. 
ARTIÈRES, Philippe. Arquivar a própria vida. Estudos Históricos, v. 11, n. 21, p.9-34, 1998. Disponível em: http://bibliotecadigital.fgv.br/ojs/index.php/reh/article/view/2061/1200. Acesso em: 27 abr. 2015.

AZEVEDO, Aroldo de; SILVA, Joaquim, PENTEADO, José de Arruda, CRETELLA JR. José, SANGIORGI, Oswaldo. Programa de Admissão. $2^{\circ}$ ed. São Paulo: Cia Editora Nacional, 1956.

BLOCH, Marc. Apologia da História, ou, $\mathbf{O}$ ofício do historiador. Tradução de André Telles. Rio de Janeiro: Jorge Zahar Ed., 2001.

CASSANY, Daniel; AYALA, Gilmar. Nativos e inmigrantes digitales en la escuela. CEE Participación Educativa, 9, nov./2008, p. 53-71. Disponível em: http://repositori.upf.edu/bitstream/handle/10230/21226/Cassany_PE_9.pdf?sequence=1. Acesso em 30 abr. 2015.

CASTILLO GÓMEZ, Antonio. El tempo de la cultura escrita. A modo de introducción. In: . (ed.). Historia de la cultura escrita: del Próximo Oriente Antiguo a la sociedad informatizada. Gijón (Asturias): Ediciones Trea, 2002, p.15-25.

CASTILLO GÓMEZ, Antonio. Historia de la cultura escrita: ideas para el debate. Revista Brasileira de História da Educação, n. 5, p. 93-124, jan./jun. 2003.

CASTILLO GÓMEZ, Antonio. Leer y escribir en la era de internet: problemas y desafios de la cultura escrita. Educação \& Realidade, v.29, n.2, p.41-53, jul./dez. 2004a. Disponível em: http://www.seer.ufrgs.br/index.php/educacaoerealidade/article/view/25391/14726. Acesso em: 23 mai. 2015.

CASTILLO GÓMEZ, Antonio. Das tabuinhas ao hipertexto. Uma viagem na história da cultura escrita. Tradução de Manuela D. Domingos. Lisboa: Biblioteca Nacional, 2004b.

CASTILLO GÓMEZ, Antonio. El hilo de Penélope y el vuelo de Ícaro. In: CASTILLO GÓMEZ, Antonio; SIERRA BLAS, Verónica Sierra Blas (coords.). El legado de Mnemosyne. Las escrituras del yo a través del tiempo. Gijón: Trea. 2007, p. 11-14.

CASTILLO GÓMEZ, Antonio. Educação e cultura escrita: a propósito dos cadernos e escritos escolares. Educação, Porto Alegre, v. 35, n. 1, p. 66-72, jan./abr. 2012.

CERTEAU, Michel de. A Escrita da história. Tradução de Maria de Lourdes Menezes. Revisão técnica de Arno Vogel. $2^{\circ}$ ed. Rio de Janeiro: Forense Universitária, 1982.

CHARTIER, Roger. Inscribir y Borrar: cultura escrita e literatura (Siglos XI-XVIII). Traducido por Vítor Goldstein. Revisado por el autor. Buenos Aires: Katz Editores, 2006. 
CHARTIER, Roger. A história ou a leitura do tempo. Tradução de Cristina Antunes. Belo Horizonte. Autêntica Editora, 2009.

COSTA, Aida, BRANDÃO, Marcius; STEMPNIEWSKI, Renato; MARINO, Aurélia. Admissão ao Ginásio. Editora do Brasil S/A, 1952.

DANTAS, Camila Guimarães. 0 passado em bits: memórias e histórias na Internet. 2008. 136f. Dissertação (Mestrado em Memória Social). Programa de Pós-Graduação em Memória Social, Universidade Federal do Estado do Rio de Janeiro (UNIRIO), Rio de Janeiro, 2008.

DOSSE, François. A História à prova do tempo: da História em migalhas ao resgate do sentido. São Paulo: Unesp, 2001.

DOSSE, François. História do tempo presente e historiografia. Tempo e Argumento. Revista do Programa de Pós-Graduação em História da UDESC, Florianópolis, v. 4, n. 1, p. 5-22, jan/jun. 2012. Disponível em:

http://revistas.udesc.br/index.php/tempo/article/view/2175180304012012005/2014. Acesso em: 23 mai. 2015.

ESCANDELL MONTIEL, Daniel. Escrituras para el siglo XXI. Literatura y blogosfera. Madrid/Frankfurt: Iberoamericana/Vervuert, 2014.

FERREIRA, Marieta de Moraes; AMADO, Janaina. Apresentação. In: Usos \& Abusos da História Oral. 2. ed.. Rio de Janeiro: FGV, 1998, p.vii-xxiv. (orgs.).

HARTOG, François. Regimes de historicidade: presentismo e experiências do tempo. Belo Horizonte: Autêntica, 2013.

KOSELLECK, Reinhart. Futuro Passado: contribuição à semântica dos tempos históricos. Rio de Janeiro: Contraponto: Ed. PUC-Rio, 2006.

LE GOFF, Jacques. História e memória. Tradução Bernardo Leitão et al. Campinas: Unicamp, 2003.

LEJEUNE, Philippe. O pacto autobiográfico: de Rousseau à Internet. Organização de Jovita Maria Gerheim Noronha. Tradução de Jovita Maria Gerheim Noronha; Maria Inês Coimbra Guedes. Belo Horizonte: Editora UFMG, 2008.

MINHOTO, Maria Angélica Pedra. Articulação entre primário e secundário na era Vargas: crítica do papel do estado. Educação e Pesquisa, São Paulo, v.34, n.3, p. 449-463, set./dez. 2008. 
MINHOTO, Maria Angélica Pedra. Da Progressão do Ensino Elementar ao Ensino Secundário (1931-1945): crítica do exame de admissão ao ginásio. Tese (Doutorado em Educação). Pontifícia Universidade Católica de São Paulo, 2007.

MUZART, Zahidé Lupinacci. De navegar e de navegantes. In: MIGNOT, Ana Chrystina Venancio; BASTOS, Maria Helena Câmara; CUNHA, Maria Teresa Santos. (orgs.). Refúgios do Eu: educação, história e escrita autobiográfica. Florianópolis: Mulheres, 2000, p. 181190.

NUNES, Clarice. O "velho" e "bom" ensino secundário: momentos decisivos. Revista Brasileira de Educação, Rio de Janeiro, nº 14, p.35-60, mai./ago. 2000.

PASSERINI, Luisa. A “lacuna” do presente. In: FERREIRA, Marieta de Moraes e AMADO, Janaina (orgs.). Usos \& Abusos da História Oral. Rio de Janeiro: FGV, 1996, p.211-214.

PESSANHA, Eurize Caldas; DANIEL, Maria Emília Borges. História da Cultura Escolar através dos exames: o caso dos Exames de Admissão ao Ginásio (1939-1971). Intermeio: revista do Mestrado em Educação, Campo Grande, MS, v. 8, n. 16, p. 4-15, 2002.

RICOEUR, Paul. Tempo e Narrativa. A intriga e a narrativa histórica. V.1. São Paulo: Editora WMF; Martins Fontes, 2010.

RICOEUR, Paul. A memória, a história, o esquecimento. Tradução de Alain François (et al.) Campinas/SP: Editora da Unicamp, 2007.

RICOEUR, Paul. La vida: un relato en busca de narrador. Ágora: Papeles de Filosofía, v. 25, n.2, p.9-22, 2006. Disponível em: http://201.147.150.252:8080/jspui/bitstream/123456789/1066/1/Ricoeur.pdf. Acesso em 05 mai. 2015.

RODRIGUES, Pedro Eurico. Do on-line para off-line. Sociabilidades e cultura escrita proporcionadas pela internet no Brasil do século XXI (2001-2010). 2012. 111 f. Dissertação (Mestrado em História). Programa de Pós-Graduação em História. UDESC, Florianópolis, 2012.

ROUSSO, Henry. O arquivo ou indício de uma falta. Estudos Históricos, Rio de Janeiro, FGV, v.9, n.17, p.85-91, 1996. Disponível em:

http://bibliotecadigital.fgv.br/ojs/index.php/reh/article/view/2019/1158. Acesso em: 10 mai 2015.

SANT'ANNA, Affonso Romano. Narrar contra o dilúvio. O Globo, Rio de Janeiro, 3 abr. 2004. Caderno Prosa \& Verso, p.2. 
SARLO, Beatriz. O tempo passado: cultura da memória e guinada subjetiva. São Paulo: Companhia das Letras; Belo Horizonte: UFMG, 2007.

SIBILIA, Paula. Em busca del aura perdida: espectacularizar la intimidad para ser alguien. Psicoperspectivas, VIII, $\mathrm{n}^{\circ} 2$ (Julio-Diciembre), 2009), p.309-329. Disponível em: http://www.psicoperspectivas.cl/index.php/psicoperspectivas/article/viewFile/83/82. Acesso em: 27 abr. 2015.

SIBILIA, Paula. O show do eu: a intimidade como espetáculo. Rio de Janeiro: Nova Fronteira, 2008.

SILVA, Cristiani Bereta da. Escrever histórias do tempo presente. Algumas questões e possibilidades. Tempos Históricos, M.C. Rondon, v. 09, p.257-276, $2^{\circ}$ sem/2006. Disponível em: http://erevista.unioeste.br/index.php/temposhistoricos/article/view/8117/6014. Acesso em: 15 de mai. 2015.

SIMÕES, Robson Fonseca. Escritas à deriva: testemunhos efêmeros sobre os tempos da escola nas comunidades do ORKUT. 2012. 239 f. Tese (Doutorado em Educação). Programa de Pós-Graduação em Educação, UERJ, Rio de Janeiro, 2012.

VIÑAO FRAGO, Antonio. Del periódico a Internet. Leer y escribir em los siglos XIX y XX. In: GÓMEZ, Antonio Castillo (ed.). Historia de la cultura escrita: del Próximo Oriente Antiguo a la sociedad informatizada. Gijón (Asturias): Ediciones Trea, 2002, p.317-381.

\section{Blogs e sites:}

Blog - Amigos de Delmiro Gouveia.

http://amigosdedelmirogouveia.blogspot.com.br/2012/05/delmiro-gouveia-lembrancasdos-tempos.html. Acesso em: 24 mar. 2014.

Blog - Anos Dourados. http://www.anosdourados.blog.br/2009/09/imagens-escola-livroadmissao-ao.html e http://www.anosdourados.blog.br/2011/02/imagens-escola-livroadmissao-ao.html. Acesso em: 24 mar. 2014.

Blog - Caminhos e Movimentos. http://tpanerai.blogspot.com.br/2006/01/o-exame-deadmissao.html. Acesso em: 24 mar. 2014.

Blog - (do) Sanharol. http://blogdosanharol.blogspot.com.br/2011/05/nos-anos-6o.html. Acesso em: 24 mar. 2014. 
Blog - marcioonline. http://marcionlinehoje.blogspot.com.br/2009/05/entre-1931-e-1971-ascriancas.html. Acesso em: 24 mar. 2014.

Site - O Baú de Macau. http://www.obaudemacau.com/?page_id=28064. Acesso em: 24 mar. 2014. 